Article

\title{
Ostracod Response to a Major Middle Jurassic Sea-Level Fall: A Case Study from Southern Tunisia (North Gondwana) with Implications on Regional Stratigraphy and Palaeoenvironmental Reconstruction
}

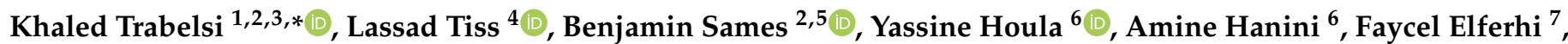
Ahmed Skanji ${ }^{7}$, Fekri Kamoun ${ }^{4}$, Mohamed Faouzi Zagrarni ${ }^{8}$ and Michael Wagreich ${ }^{2}(\mathbb{D}$

check for

updates

Citation: Trabelsi, K.; Tiss, L.;

Sames, B.; Houla, Y.; Hanini, A.; Elferhi, F.; Skanji, A.; Kamoun, F.;

Zagrarni, M.F.; Wagreich, M.

Ostracod Response to a Major Middle

Jurassic Sea-Level Fall: A Case Study from Southern Tunisia (North Gondwana) with Implications on Regional Stratigraphy and Palaeoenvironmental Reconstruction. Geosciences 2022, 12, 93. https:// doi.org/10.3390/geosciences12020093

Academic Editors: Pierre Pellenard, Emanuela Mattioli, Guillaume Dera and Jesus Martinez-Frias

Received: 3 January 2022

Accepted: 7 February 2022

Published: 17 February 2022

Publisher's Note: MDPI stays neutral with regard to jurisdictional claims in published maps and institutional affiliations.

Copyright: (c) 2022 by the authors. Licensee MDPI, Basel, Switzerland. This article is an open access article distributed under the terms and conditions of the Creative Commons Attribution (CC BY) license (https:// creativecommons.org/licenses/by/ $4.0 /)$.
1 Department of Earth Sciences, Faculty of Sciences of Sfax, University of Sfax, Sfax 3038, Tunisia

2 Department of Geology, Faculty of Earth Sciences, Geography and Astronomy, University of Vienna, Althanstrasse 14, 1090 Vienna, Austria; benjamin.sames@univie.ac.at (B.S.); michael.wagreich@univie.ac.at (M.W.)

3 LR18ES07, Department of Earth Sciences, Faculty of Sciences of Tunis, University of Tunis El Manar II, Tunis 1068, Tunisia

4 LR GEOGLOB, Department of Earth Sciences, Faculty of Sciences of Sfax, University of Sfax, Sfax 3038, Tunisia; tisslassad30@gmail.com (L.T.); fekrik@yahoo.fr (F.K.)

5 Sam Noble Oklahoma Museum of Natural History, 2401 Chautauqua Ave., Norman, OK 73072-7029, USA

6 Département de la Géologie, Office National des Mines, 24 Rue de l'énergie 2035 la Charguia, BP.215, Tunis 1080, Tunisia; yahoula.hy@gmail.com (Y.H.); amine.hanini@onm.nat.tn (A.H.)

7 Entreprise Tunisienne d'Activités Pétrolières (ETAP), 54 Avenue Mohamed, Tunis 1002, Tunisia; faycelferhi@gmail.com (F.E.); ahmedskanji@gmail.com (A.S.)

8 U. R. Applied Hydrosciences UR13ES81, Higher Institute of Water Sciences and Techniques, University of Gabes, Cité Erryadh, Gabes 6072, Tunisia; zagrarni_m_f@yahoo.fr

* Correspondence: trabkhalfss@yahoo.fr

Abstract: Marginal-marine to non-marine ostracod assemblages from the Bajocian (Mid-Jurassic) of southern Tunisia, precisely from the Krachoua Formation at the Kef El Anneba section near the Beni Kheddache area, are here described and tested for their utility to improve the stratigraphic accuracy and palaeoenvironmental reconstructions. This particular microfauna consists of 11 species belonging to 6 genera and represents 2 distinct types of species-rich assemblages from this time interval, allowing the interpretation of the depositional setting of the fossiliferous horizon from which the samples derive. The first ostracod assemblage is mainly composed of the brackish to shallow marine species Fastigatocythere sp. Mette, 1995; Vernoniella aff. V. bajociana Bate, 1965b; Paracypris sp. A, Paracypris sp. B, Fabanella sarda Malz et al., 1985; Marslatourella aff. M. bathonica Andreu, 1999; and Fabanella aff. F. bathonica Oertli, 1957. This ostracod biofacies reflects marginal marine (shallow platform, restricted lagoon) conditions in the studied area. In contrast, the second ostracod assemblage is exclusively dominated by the non-marine limnic species Alicenula sp., Theriosynoecum pusilla Rohr, 1976; Theriosynoecum aff. T. aveyronensis Rohr, 1976; and Theriosynoecum sp. Such ostracod biofacies reflects the establishment of (a) permanent freshwater lake(s) in the studied area, triggered by the total emersion of the Bajocian Krachoua platform, presumably as response to the short-term sea-level fall event JBj3 of Haq (2017). The recognized ostracod species from the upper part of the Krachoua Formation at Kef El Anneba section (Medenine area) are particularly similar to those already described from the neighbouring sections of Kezzani (Dhaher area) and Krachoua (Tataouine area), facilitating a stratigraphic calibration of the Krachoua Formation, as well as regional correlations of the respective Bajocian continental event within the southern Tunisian palaeogeographic domain. Moreover, the biogeography of the studied ostracod microfauna from the Mid-Jurassic of southern Tunisia provides further arguments to support the hypothesis of significant biological exchanges between Laurasian and Gondwanan islands, as recently demonstrated by means of a charophyte microflora, indicating that Peri-Tethyan biogeography remained relatively uniform during that time interval and challenging the previous assumption of their endemism. 
Keywords: ostracods; depositional environments; regional stratigraphic correlation; Krachoua Formation; Middle Jurassic; North Gondwana; southern Tunisia

\section{Introduction}

The detection of key emersion surfaces is fundamentally based on sedimentological criteria (e.g., desiccation cracks, karstification) but can also be revealed by remarkable changes in the microfaunistic assemblages in long-term marginal-marine depositional settings. In the present work, we use ostracods as tool to interpret the stratigraphy and the depositional palaeoenvironment of the Bajocian mixed series of the Krachoua Formation of southern Tunisia (Figure 1), northern margin of Gondwana. Although Middle Jurassic ostracod microfaunas have been described from the northwestern Tethyan margin in a number of publications and applied to biostratigraphy, palaeoecology and palaeobiology (e.g., [1-18]), they are still poorly documented from the southern/southwestern margin of the Tethys, and especially records from the southern Tunisian margin have only been studied by $[19,20]$ thus far or just mentioned by [21]. Accordingly, Refs. [19,20] have only reported Bajocian ostracods from the southern part of south Tunisia called the Tataouine basin, precisely from the Krachoua Formation at its type locality Krachoua section, where this fauna was composed of the species leguminella, Darwinula techoutensis, Theriosynoecum alatum, Limnocythere sp., Timiriasevia uptoni, Fastigatocythere sp., Fabanella sarda, Pneumatocythere? cf. sp. 1, and Pontocyprella sp. 1 described from the type locality of the Krachoua section. However, ref. [21] just noted the presence of four species, Limnocythere sp., Bisulcocypris? calcar, Praeschuleridea sp., and Ektyphocythere sp., at the Kazzani section of the Dahar locality, from the same Tataouine area.

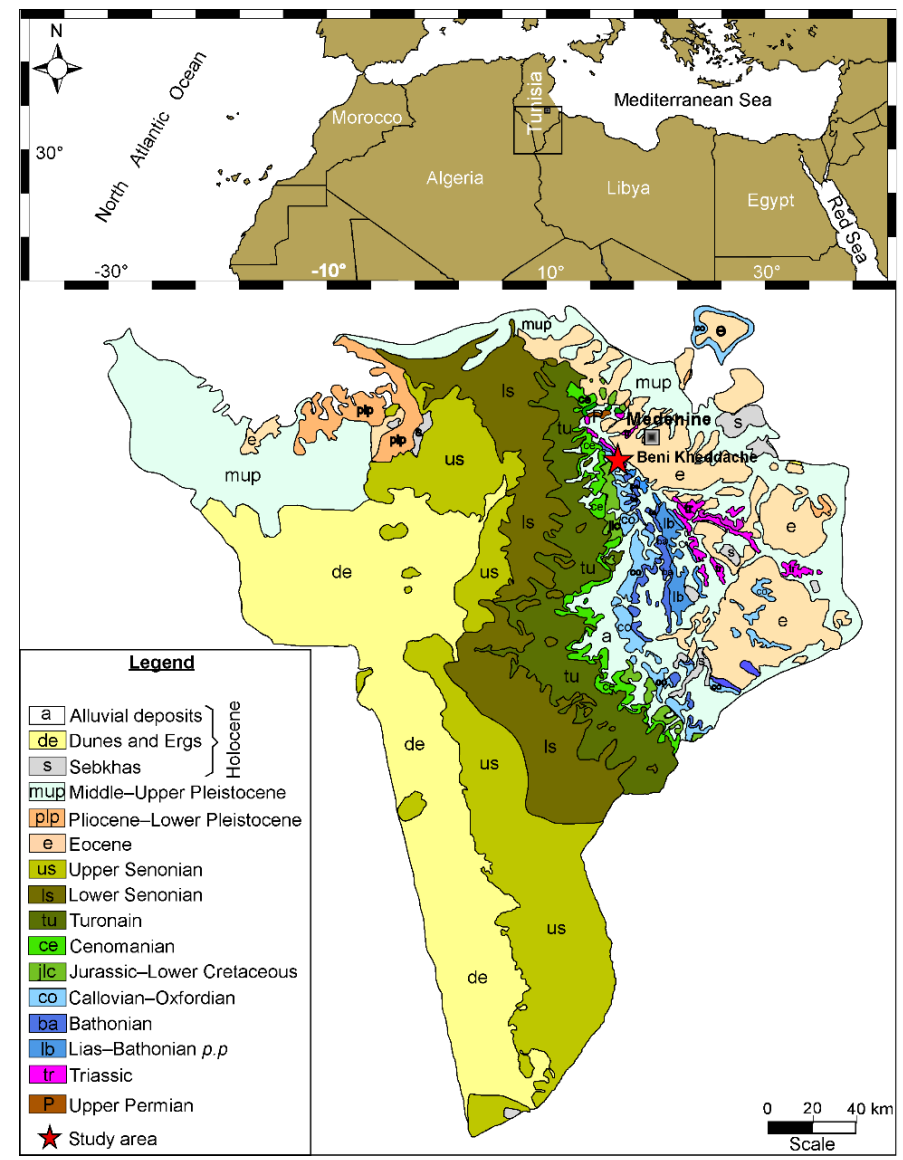

Figure 1. Geographical and geological setting of the study area (modified from [22]). 
In the present work, however, we investigate the Mid-Jurassic (Bajocian) ostracod assemblages from the new Kef El Anneba section of the Krachoua Formation in the Medenine area, northern southern Tunisian domain. These assemblages are compared with their coeval, poorly known microfauna from the Tataouine area in order to give more accuracy to the stratigraphy of the studied series in this palaeogeographic domain, its respective depositional environment, and its consideration for supra-regional correlation and palaeobiogeography.

\section{Geological Setting}

The Jurassic successions of southern Tunisia are primarily composed of shallow marine calcareous formations with significant lateral variations in thickness and facies associated with stratigraphic unconformities and hiatuses (Figure 1), mainly controlled by tectono-eustatic factors. These deposits have been documented in a number of studies on lithostratigraphy [22-25], sedimentology [24,26,27], structural geology [28], as well as biostratigraphy and chronostratigraphy [29-33].

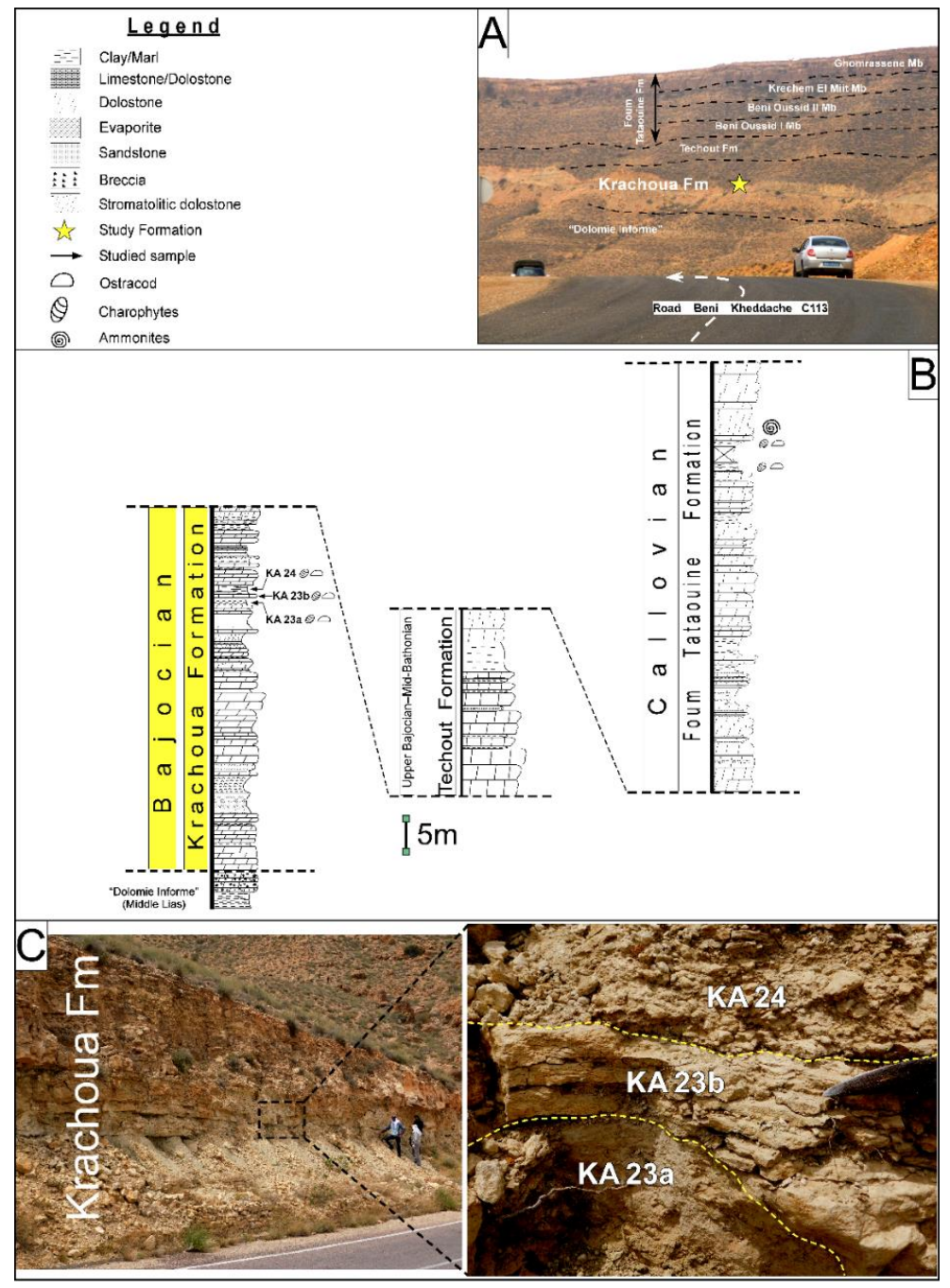

Figure 2. Stratigraphy of the studied Kef El Anneba section: (A) panoramic view of the studied section in the Beni Kheddache area with lithostratigraphic units marked; (B) lithostratigraphic column of the studied section showing the ostracod-bearing beds within the Krachoua Formation; (C) outcrop pictures of the marlstone bed KA 23a, the limestone bed KA 23b, and the marly limestone KA 24 yielding the studied Bajocian ostracod microfauna. 
The Middle Jurassic of southern Tunisia is mainly composed of three lithostratigraphic units (Figure 2A-C), interpreted as transgressive-regressive sequences which, from base to top, are the Krachoua Formation, the Techout Formation, and the Foum Tataouine Formation [21,27]. Indeed, the Krachoua Formation, Bajocian in age [20,21,24,32,33], lies unconformably on top of the "Dolomie informe", a dolomite breccia which is Lower Jurassic (Pliensbachian) in age [22], and is overlain by the Techout Formation, Upper Bajocian-Middle Bathonian in age [20,21,24]. This series is ca. 50 m-thick at the Kef El Aneba section of the Beni Kheddache area (Figure 2), located $30 \mathrm{~km}$ west of the city of Medenine in southeastern Tunisia (cf. Figure 1), showing minor successive backstepping sequences mainly formed of gypsum (and or sands), dolomites, and marine limestones. Recent micropalaeontological investigation of this series revealed rich charophyte-bearing beds [33] from which the present studied ostracod fauna were recovered (Figure 2B,C).

\section{Material and Methods}

Bulk samples were collected from the marl KA 23a, the limestone KA 23b, and the marly limestone KA 24 levels (Figure 2B,C) of the Krachoua Formation. Marlstone sample was treated using the traditional sieving method, whereas limestone samples were treated using acetolysis. This latter method, first advocated by [34], has successfully been applied by [33,35-38] to recover well-preserved microfossils (charophytes and ostracods) from hard calcareous rocks. It consists of taking a completely dry sample of calcareous rock that has been mechanically comminuted with a jaw crusher machine into fragments measuring 1-3 mm across and adding similar amounts of anhydrous acetic acid and anhydrous copper sulphate (acid attacks in an exothermic reaction). After neutralization by ammoniac, the residue is treated with ultra-sound and then washed and rinsed. Scanning electron microscopy on selected gold-sputtered specimens was conducted with a Jeol JSM-6400 at the Faculty of Earth Sciences, Geography and Astronomy, University of Vienna (Austria), and a Jeol JSM-5400 at the Tunisian Petroleum Company (ETAP), Tunis (Tunisia).

The studied ostracod specimens are housed in the National Geological Heritage Service (Service de Patrimoine Nationale Géologique, SPNG) of the Tunisian National Office of Mines in Tunis (Office National des Mines de Tunis-ONM), under the reference "Collection of non-marine Mesozoic microfossils of Tunisia".

\section{Result: Systematic Description}

The description of the listed ostracod species herein is not given in detail, as none of them are new. The stratigraphic distribution of the identified species in the studied section is presented in Figure 3, and their illustration is in Figure 4. The classification scheme follows [39] for the taxa of family level and above, complemented by [40,41], and other specific literature for the taxa of family level and below.

Class OSTRACODA Latreille, 1806

Order PODOCOPIDA Sars, 1866

Suborder CYPRIDOCOPINA Jones, 1901

Superfamily CYPRIDOIDEA Baird, 1845

Family CANDONIDAE Kaufmann, 1900

Subfamily PARACYPRIDINAE Sars, 1823

Tribe Paracypridini SARS, 1923

Genus Paracypris Sars, 1866

Paracypris sp. A

(Figure 4E) 


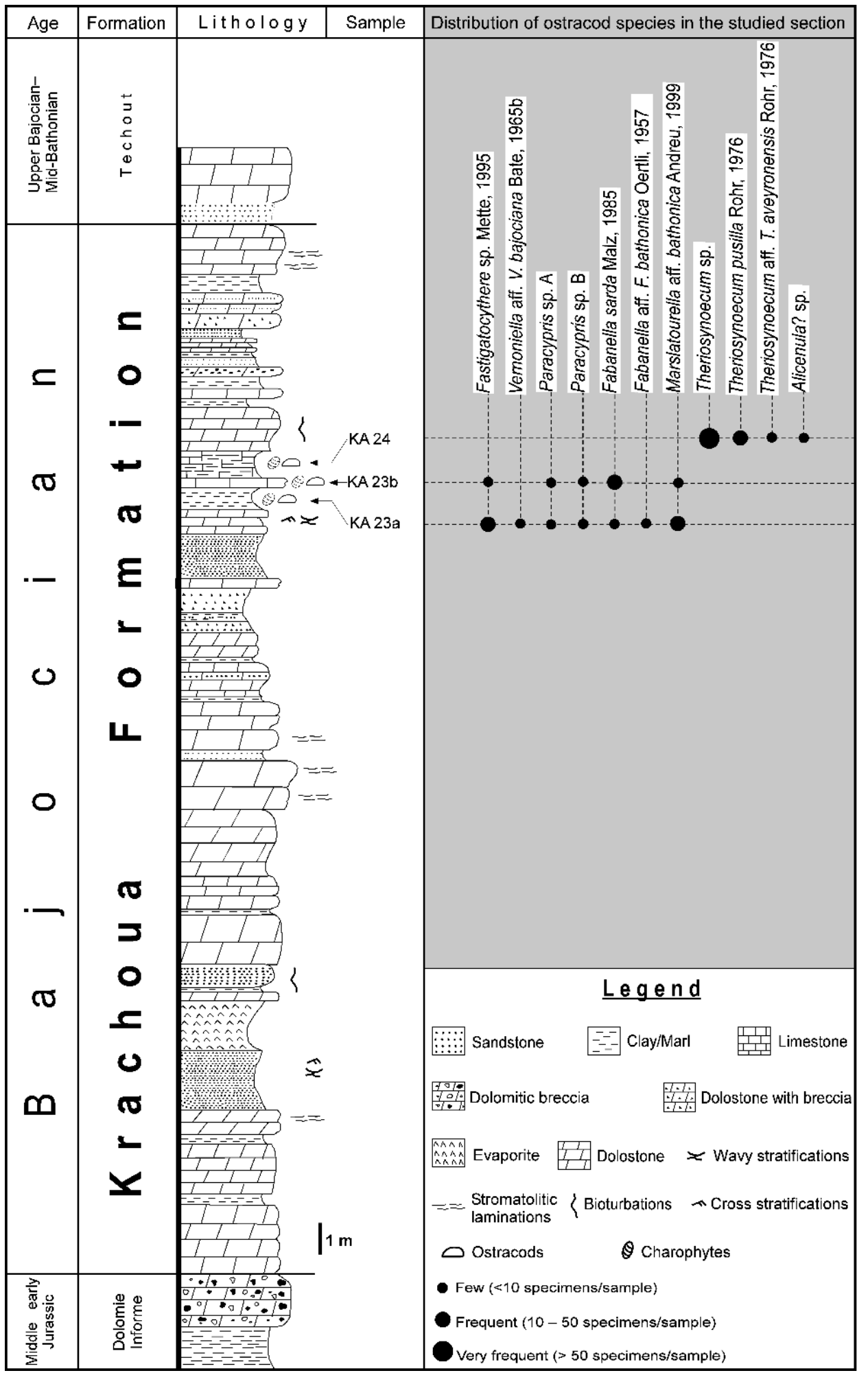

Figure 3. Distribution of ostracod species in the Krachoua Formation of the Kef El Anneba section, Beni Kheddache, Medenine area.

Remarks: A species of the genus Paracypris with particularly high anterior part, dorsal margin straight and strongly inclined towards the posterior end. The specimens are badly preserved. 
Occurrence and stratigraphic range (herein): Marlstone level KA 23a and limestone level KA 23b (Figure 3), upper part of the Bajocian Krachoua Formation, Beni Kheddache section, Medenine area, southern Tunisia.

Paracypris sp. B

(Figure 4F1,F2)

?2017. Paracypris sp. 2-Soulimane et al., p. 13, fig. 5g [42].

Occurrence and stratigraphic range (herein): Marlstone level KA 23a and limestone level KA 23b (Figure 3), upper part of the Bajocian Krachoua Formation, Beni Kheddache section, Medenine area, southern Tunisia.

Remarks: Our studied specimens show great resemblance to Paracypris sp. 2 of Soulimane et al., 2017 [42], except that our specimens are on average $100 \mu \mathrm{m}$ larger, probably reflecting a more advanced ontogenetic stage, or even consisting of a new different species. As this species is quite rare in the studied material, its attribution to Paracypris sp. of Soulimane et al., 2017 [42] remains questionable, and our species is left in open nomenclature.

Suborder CYTHEROCOPINA Baird, 1850

Superfamily CYTHEROIDEA Baird, 1859

Family PROGONOCYTHERIDAE Sylvester-Bradley, 1948

Subfamily PROGONOCYTHERINAE Sylvester-Bradley, 1948

Genus Fastigatocythere Wienholz, 1967 [18]

Fastigatocythere sp. Mette, 1995 [19]

(Figure 4G1-G4)

1995. Fastigatocythere sp.-Mette, p. 336, pl. 21, figs. 1-4.

Remarks: Our studied specimens match the diagnostic features of Fastigatocythere sp. Mette, 1995 [20].

Occurrence and stratigraphic range (herein): Marlstone level KA 23a and limestone level KA 23b (Figure 3), upper part of the Bajocian Krachoua Formation, Beni Kheddache section, Medenine area, southern Tunisia.

Occurrence and stratigraphic range elsewhere: Middle Jurassic (Bajocian), Krachoua Formation, Krachoua section, Tataouine area, southern Tunisia [20,21].

Family CYTHERIDAE Baird, 1850

Genus Marslatourella Malz, 1959

Marslatourella aff. M. bathonica Andreu et al., 1999 [1]

(Figure 4B1-B3)

1968. Klieana sp.-Dépêche, pl. 1, fig. 10 [44].

1999. Marslatourella bathonica n. sp.-Andreu et al., p. 199, pl. 2, figs. 15-21 [1].

?1995. Fabanella sp. 1-Mette, pl. 8, figs. 5,6, 8 [19].

Remarks: Specimens of this species are relatively rare and moderately preserved but show a similar outline and ornamentation as the species Marslatourella bathonica of Andreu, 1999 [1], from the Bathonian of France. The species Fabanella sp. 1 described by [19] from southern Tunisia seems to have erroneously been assigned to the genus Fabanella, while it clearly displays the diagnostic feature of the genus Marslatourella and shows an especially great affinity to the species M. bathonica Andreu et al., 1999 [1].

Occurrence and stratigraphic range (herein): Marlstone level KA 23a (Figure 3), upper part of the Bajocian Krachoua Formation, Beni Kheddache section, Medenine area, southern Tunisia.

Occurrence and stratigraphic range elsewhere: Marslatourella bathonica Andreu, 1999 [1] to which our studied specimens show great affinity has been reported from the Bathonian of France in lake environments [1,44] and has also been reported from the Bajocian of southern Tunisia $[19,20]$.

Family CYTHERIDEIDAE Sars, 1925

Genus Fabanella Martin, 1961

Fabanella aff. F. bathonica (Oertli, 1957) [14]

(Figure 4C) 


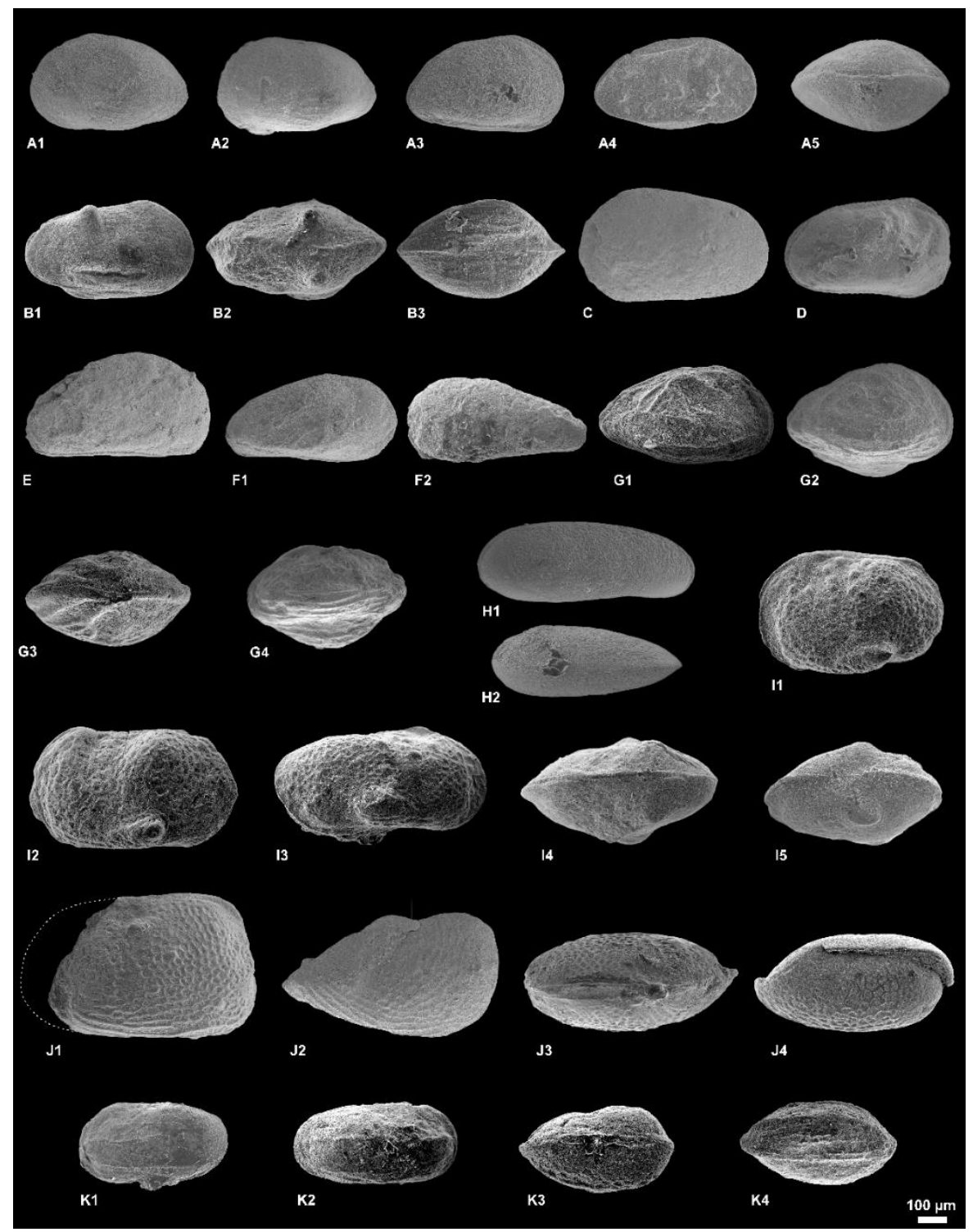

Figure 4. The studied ostracod microfauna from the Bajocian Krachoua Formation at Kef El Anneba section, Beni Kheddache, Medenine area. (A1-A5) Fabanella sarda Malz et al., 1985 [43], SPNG-202101-05, rock samples KA 23a and KA 23b (Krachoua Fm); (A1,A2) Left lateral view of adult carapace, (A3) Right lateral view of adult carapace, (A4) Internal view of left valve, (A5) Dorsal view of adult carapace. (B1-B3) Marslatourella aff. M. bathonica Andreu, 1999 [1], SPNG-2021-06-08, rock samples KA 23a and KA 23b (Krachoua Fm); (B1) Right lateral view of adult carapace, (B2) Dorsal lateral view of adult carapace, (B3) Ventral view of adult carapace. (C) Fabanella aff. F. bathonica (Oertli, 1957) [14], SPNG-2021-09, rock samples KA 23a (Krachoua Fm), left lateral view of adult carapace. (D) Vernoniella aff. V. bajociana Bate, 1965b [6], SPNG-2021-10, rock samples KA 23a (Krachoua Fm), right lateral view of adult carapace. (E) Paracypris sp. A, SPNG-2021-11, rock samples KA 23a and KA 23b (Krachoua Fm), right lateral view of adult carapace. (F1,F2) Paracypris sp. B, SPNG-2021-12-13, rock samples KA 23a and KA 23b (Krachoua Fm); (B1) Right lateral view of adult carapace, (B2) Left lateral view of adult carapace. (G1-G4) Fastigatocythere sp. Mette, 1995 [19], SPNG-2021-14-17, rock samples KA 23a and KA 23b (Krachoua Fm); (G1) Right lateral view of adult carapace, (G2) Left lateral view of adult carapace, (G3) Dorsal view of adult carapace, (G4) Ventral view of adult carapace. (H1,H2) Alicenula? sp., SPNG-2021-17-18, rock samples KA 24 (Krachoua Fm); (H1) Left lateral view of adult carapace, (H2) Dorsal view of adult carapace. (I1-I5) Theriosynoecum sp., SPNG-2021-19-20, rock samples KA 24 (Krachoua Fm); (I1,I2) Left lateral view of adult female carapace, (I3) Right lateral view of male adult carapace, (I4) Dorsal view of adult carapace, A5: Ventral view of adult carapace. 
(J1-J4) Theriosynoecum aff. T. aveyronensis Rohr, 1976 [15], SPNG-2021-21-22, rock samples KA 24 (Krachoua Fm); (J1) Right lateral view of adult broken carapace, (J2) Right lateral view of adult deformed carapace, (J3) Dorsal view of adult carapace, (J4) Ventral view of adult carapace. (K1-K4) Theriosynoecum pusilla (Rohr, 1976) [15], SPNG-2021-23-26, rock samples KA 24 (Krachoua Fm); (K1) Left lateral view of adult carapace, (K2) Right lateral view of adult carapace, (K3) Dorsal view of adult carapace, (K4) Ventral view of adult carapace.

1957 Cyprideis? bathonica sp. nov.-Oertli in Bernard et al., p. 758-761, pl. 21, figs. 12-20; pl. 22, figs. 1-6, 12 [14].

1963. Fabanella bathonica-Oertli, pl. 28, fig. m [10].

1967. Fabanella bathonica-Bate, p. 33, pl. 4, figs. 1-5 [7].

1968. Fabanella bathonica-Dépêche, pl. I, fig. 16 [44].

1976. Fabanella bathonica-Rohr, 38, pl. 4, figs. 1-15 [15].

1984. Fabanella bathonica-Dépêche, 327, pl. 5, fig. 10 [11].

1985. Fabanella bathonica-Dépêche, pl. 28, fig. 3 [12].

1995. Fabanella bathonica-Mette, pl. 7, figs. 11-12, pl. 8, figs. 1-4 [19].

Remarks: Specimens of this species are relatively rare and moderately to badly preserved. According to the resemblance in general shape and outline, our specimens show great affinity to Fabanella bathonica.

Occurrence and stratigraphic range (herein): Marlstone level KA 23a (Figure 3), upper part of the Bajocian Krachoua Formation, Beni Kheddache section, Medenine area, southern Tunisia.

Occurrence and stratigraphic range elsewhere: This species is widely distributed in the Bathonian of France [1,9-12,15], England [7], and southern Tunisia [19,20].

Fabanella sarda Malz et al., 1985 [43]

(Figure 4A1-A5)

1985. Fabanella sarda n. sp.-Malz et al., p. 315, pl. I, figs. 4-11; pl. 2, figs. 12-18 [43].

1995. Fabanella sarda-Mette, p. 310, pl. 7, figs. 3, 6-10 [19].

Remarks: Specimens of this species are abundant and moderately preserved with both valves and carapaces present in the studied samples allowing its unambiguous identification.

Occurrence and stratigraphic range (herein): Marlstone level KA 23a (Figure 3), upper part of the Bajocian Krachoua Formation, Beni Kheddache section, Medenine area, southern Tunisia.

Occurrence and stratigraphic range elsewhere: This species has been recorded from the Middle Jurassic (Bajocian to lower Bathonian) of Sardinia [43], as well as of southern Tunisia $[19,20]$.

Subfamily CYTHERIDEINAE Sars, 1925

Genus Vernoniella Oertli, 1957 [14]

Vernoniella aff. V. bajociana Bate, 1965b [6]

(Figure 4D)

1965b. Vernoniella bajociana sp. nov.-Bate, pl. 13, figs. 6-11; pl. 14, figs. 1-13 [6].

Remarks: Although relatively rare and moderately preserved, our studied specimens in general display the same diagnostic features of Vernoniella bajociana species as it has originally been described by [6].

Occurrence and stratigraphic range (herein): Marlstone level KA 23a (Figure 3), upper part of the Bajocian Krachoua Formation, Beni Kheddache section, Medenine area, southern Tunisia.

Occurrence and stratigraphic range elsewhere: Vernoniella bajociana has been described from the Middle Jurassic (Bajocian) of Yorkshire, England [6], Glyptocythere sciutula ostracod zone, Stephanoceras humphresianum ammonite zone [8] (p. 205).

Family LIMNOCYTHERIDAE Sars, 1925

Sub-family TIMIRIASEVIINAE Mandelstam, 1960

Genus Theriosynoecum Branson, 1936 [45] 
Remark: Regarding the synonymization of Bisulcocypris and Theriosynoecum, the former being a junior synonym of the latter, see [45] (p. $300 \mathrm{ff}$.$) .$

Theriosynoecum aff. T. aveyronensis (Rohr, 1976) [15]

(Figure 4J1-J4)

1976. Bisulcocypris aveyronensis n. sp.-Rohr, p. 150, pl.8, figs. 1-12 [15].

1999. Theriosynoecum aveyronensis (Rohr) comb. nov.-Andreu, p. 197, pl. 1, figs. 1-11 [1]. 1995. Theriosynoecum sp. 1-Mette, p. 276, pl. 10, figs. 9-10, pl. 11, figs. 1-4 [19]

?1995. Theriosynoecum? sp. 1-Mette, p. 277, pl. 11, figs. 5-9 [19]

Remarks: Specimens of this species are scarce and moderately to badly preserved with partly incomplete carapaces in the studied material. These are similar in size, outline, and ornamentation to Theriosynoecum aveyronensis Rohr, 1976 [15]. Ref. [19] described adults and juveniles of Theriosynoecum sp. 1 from the lower Techout and lower Tataouine formations (lower Bathonian-middle Callovian) of southern Tunisia and mentions similarities to Theriosynoecum aveyronensis Rohr, 1976 [15]. Because of the moderate preservation and insecure determination of our material, we questionably synonymize these species. Theriosynoecum? sp. 1 of Mette (1995) [19], also from the lower Techout and Tatauoine formations of southern Tunisia, most probably represents non-noded juveniles of Theriosynoecum daharense Mette, 1995 [19] (and) or Theriosynoecum sp. 1 of Mette (1995) [19]. In addition, Ref. [19] had already noted that his Theriosynoecum sp. 1 shows some affinity to Theriosynoecum aveyronensis Rohr, 1976 [15] but differs from it in the rounded posterior margin, the more pronounced two anterodorsal furrows, and the incurvation of the posterior margin (dorsal view). However, it seems that these differences are not regularly maintained within the figured specimens of Mette (1995) [19], and that could be the result of calcification and/or preservation degrees, and therefore, this species should be assigned to Theriosynoecum aveyronensis Rohr, 1976 [15], as clearly stated and discussed by [15] (p. 195): "These juvenile stages are very close, both morphologically and ornamental, to those of Theriosynoecum? sp. 1 Mette, 1995 [19], from the lower Bathonian of Tunisia".

Occurrence and stratigraphic range (herein): Marly limestone level KA 24 (Figure 3), upper part of the Bajocian Krachoua Formation, Beni Kheddache section, Medenine area, southern Tunisia.

Occurrence and stratigraphic range elsewhere: This species has been described from the Middle Jurassic (Bathonian) of France [1,15] and southern Tunisia [19,20].

Theriosynoecum pusilla (Rohr, 1976) [15]

(Figure 4K1-K4)

1976. Bisulcocypris pusilla n. sp.-Rohr, p. 152, pl.9, figs. 11-22 [15]

?1985. Theriosynoecum sp. juv.-Malz et al., p. 309., pl. 9, figs. 91-94 [43]

Remarks: Specimens of this species are quite abundant and moderately preserved in the studied material. Size, outline, shape, and ornamentation match the species Theriosynoecum pusilla Rohr, 1976 [15].

Occurrence and stratigraphic range (herein): Marly limestone level KA 24 (Figure 3), upper part of the Bajocian Krachoua Formation, Beni Kheddache section, Medenine area, southern Tunisia.

Occurrence and stratigraphic range elsewhere: This species has previously been described from the Middle Jurassic (Bathonian) of France [9,15] and Sardinia [9,43], northern Tethyan margin. The authors of [43] mention and figure juvenile (?) specimens identified as Theriosynoecum sp. with similarities to T. pusilla Rohr, 1976 [8], from the lower Bajocian of northwestern Sardinia. The Tunisian species herein represent its first record from the southern Tethyan margin.

Theriosynoecum sp.

(Figure 4I1-I5)

?1995. Limnocythere sp.-Mette, p. 275, pl. 9, figs. 2-4 [19]

Remarks: This species is very abundant and relatively well preserved in the studied material. It displays a similar general shape and (partly ornamentation) like Limnocythere sp. of Mette (1995) [19], particularly with regard to the distinct ventrolateral bulge. However, 
the figured specimens of Mette (1995) [19] seem to be somewhat deformed and potentially represent late pre-adult morphs of Theriosynoecum, not Limnocythere, based on overall morphology (cf. Sames, 2011a [46]), with strong local ornamentation elements, i.e., nodes, which are ecophenotypic $[46,47]$. As ref. [19] noted, this Limnocythere sp. probably represents a new species. We do agree, but we would assign this species to Theriosynoecum. The synonymy of Mette's species (1995) [19] with our material cannot be securely confirmed thus far, although both occur in about the same stratigraphic interval of the upper Krachoua Formation.

Occurrence and stratigraphic range (herein): Marly limestone level KA 24 (Figure 3), upper part of the Bajocian Krachoua Formation, Beni Kheddache section, Medenine area, southern Tunisia.

Occurrence and stratigraphic range elsewhere: This species is potentially known from the Middle Jurassic (upper Bajocian?-lower Bathonian) of the upper Krachoua Formation in the Krachoua area, southern Tunisia $[19,20]$.

Suborder DARWINULOCOPINA Sohn, 1988

Superfamily DARWINULOIDEA Brady and Norman, 1889

Family DARWINULIDAE Brady and Norman, 1889

Genus Alicenula Rossetti and Martens, 1998

Alicenula? sp.

(Figure 4H1,H2)

?1995. Darwinula cf. leguminella (Forbes, 1855)—Mette, p. 272. pl. 6, figs. 13-17 [19]

Remarks: Specimens of this species are relatively rare and moderately to badly preserved in the studied material. Our specimens show some affinities to Darwinula cf. leguminella described by [19] from the upper Krachoua Formation of Tunisia in outline (especially the convex dorsal outline), and shape. The preservation precludes secure identification. Darwinula leguminella has newly been combined into Alicenula by [48], however, the validity of the application of extant genus names to Mesozoic Darwinulidae needs revision aside from the fact that it must be based on internal valve features as well. Moreover, the presumed extreme long stratigraphic range of some Mesozoic species might be true (cf. Martens et al., 2003 [48], for example, for reasons) but also needs to be tested. Indeed, the cosmopolitan Alicenula? leguminella is a typical Lower Cretaceous taxon. The Bajocian species from Tunisia thus probably represents a new species.

Occurrence and stratigraphic range (herein): Marly limestone level KA 24 (Figure 3), upper part of the Bajocian Krachoua Formation, Beni Kheddache section, Medenine area, southern Tunisia.

Occurrence and stratigraphic range elsewhere: Not applicable.

\section{Discussion}

\subsection{Ostracod Assemblages and Depositional Palaeoenvironments}

The fossiliferous horizon from the upper part of the Krachoua Formation contain 3 ostracod-bearing beds, KA 23a, KA 23b, and KA 24, which yielded 11 species belonging to 6 genera and distributed through 2 types of assemblage (Figure 5): 


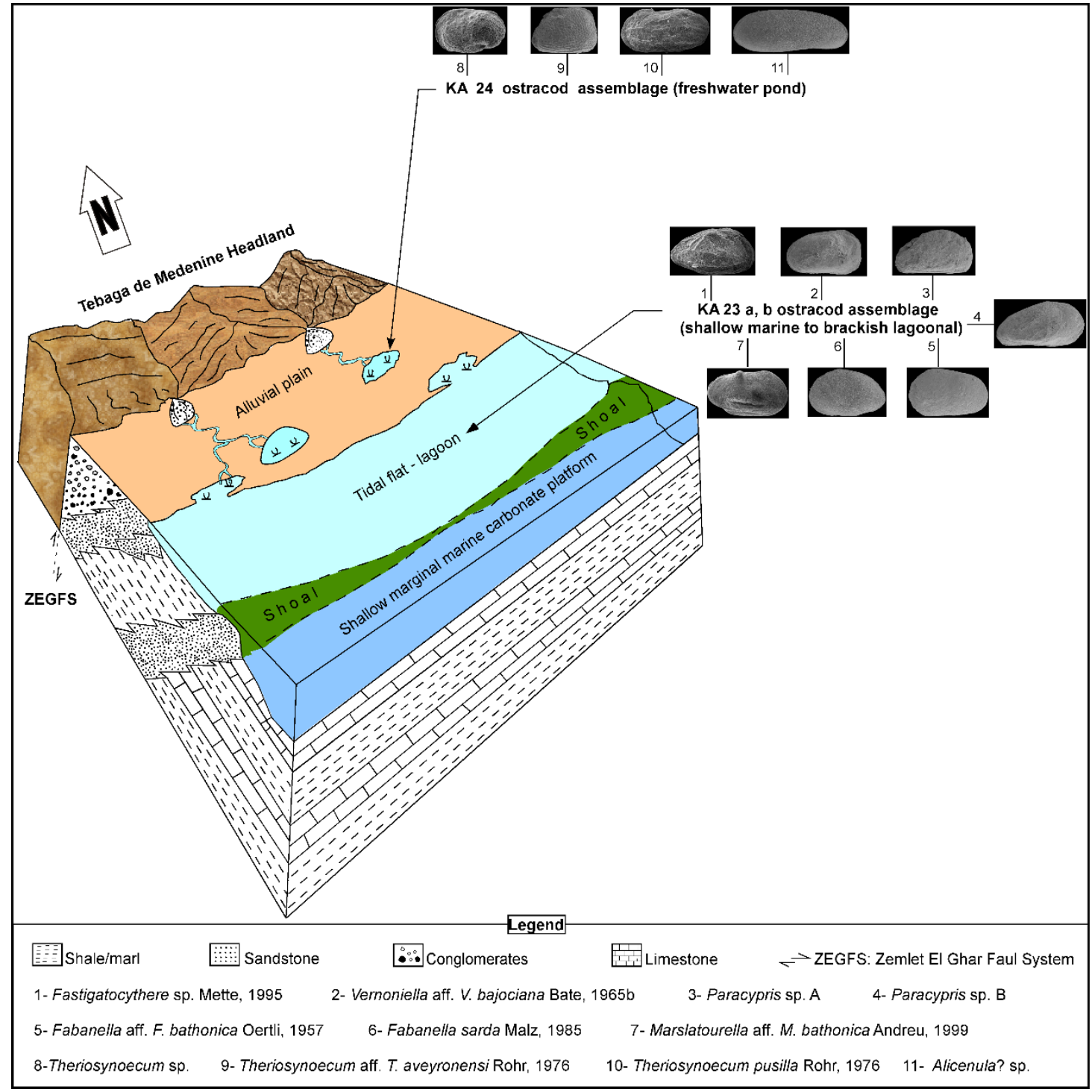

Figure 5. Palaeoenvironmental model summarising the ostracod distribution in the Krachoua Formation at the studied Beni Kheddache section, Medenine area, during the Bajocian (modified from [20]).

1. Fastigatocythere sp.-Fabanella sarda assemblage is the most abundant species from the Beds KA 23a, KA 23b. It is a non-balanced assemblage, as reflected in the dominance of shallow marine species (Fastigatocythere sp. Mette, 1995 [19], Vernoniella aff. V. bajociana Bate, 1965b [6], Paracypris sp. A, and Paracypris sp. B) compared to the brackish ones (Fabanella sarda Malz et al., 1985 [43], Marslatourella aff. M. bathonica Andreu, 1999 [1], and Fabanella aff. F. bathonica Oertli, 1957 [14]). Adapted to the marly (KA 23a) or carbonate-rich (KA 23b) substrate, the ostracod fauna from these levels strongly suggests an inner shallow shelf and/or peritidal environment differentiated into restricted lagoons as already confirmed by the associated charophyte flora [33], as well as the benthic foraminifers, echinoid and gastropod remains [24]. Ref. [20], on the basis of detailed quantitative and qualitative palaeoecological analyses of a coeval ostracod biofacies in the upper part of the Krachoua Formation from the Tataouine basin, southward of our studied locality, suggested a shallow to marginal marine depositional environment for the respective series. In our Kef El Anneba section from the Medenine area, however, we record the presence of additional representative species of the shallow marine genera Vernoniella, Paracypris, and Fastigatocythere, which were already present with Pontocyprella in the Tataouine area $[19,20]$, possibly reflecting more influence of marine conditions and more connections to the sea, respectively, during 
that time interval. Consequently, it seems that the associated brackish species Fabanella sarda and Fabanella aff. bathonica in our ostracod assemblages from beds KA 23a and KA 23b might have been opportunistic and developed during a time of a more restricted lagoon and/or increasing freshwater input, allowing the prevalence of oligo-mesohaline conditions in the depositional environment. Indeed, the species Fabanella bathonica associated to Darwinula incurva, Bisulcocypris [recte Theriosynoecum] aveyronensis has been interpreted by [49] as indicative of strongly reduced salinity in the Lower Bathonian (Jurassic) of the Causses (southern France).

2. Theriosynoecum pusilla-Theriosynoecum sp. assemblage, with accompanied species Theriosynoecum aff. T. aveyronensis (Rohr, 1976) [15], and Alicenula? sp. The dominance and abundance of species of the Limnocytheridae and Darwinulidae in this assemblage from the marly limestone bed KA 24 reflects freshwater (to slightly oligohaline) conditions [38,50-53] and the presence of permanent water bodies, i.e., lakes $[7,41,54]$. This quintessentially corresponds to the limnic Theriosynoecum-Darwinula assemblage of Mette (1997) [20] from the upper Krachoua Formation in the Tataouine area, about $60 \mathrm{~km}$ southward of our studied locality, interpreted by this author as strictly freshwater ostracod biofacies. Such a non-marine setting is supported by the associated highly diverse and abundant charophyte assemblages having recently been described from the same section by [33].

In sum, from the taphonomic point of view, the abundance of closed carapaces in the studied ostracod assemblages indicates limited transportation, a soft substratum and a relatively high rate of sedimentation, and an in situ fauna [36,38,54-56]. Furthermore, the presence of some species with only adults or the final larval stage points to some occasional post-mortem disturbances (by current, wave, or biological activity) within a context of lowto high-energy thanatocoenoses [56] or gradational thanatocoenoses [36,38,57-59], pointing to autochthonous ostracod assemblages in the depositional environment. Such a hypothesis is also supported by the well-preserved and diversified associated charophyte microflora recently described from the studied section [33], and equally the associated gastropods and foraminifera [21,24].

The upward stepwise shift in our studied locality from marginal marine (beds KA 23a and KA 23b) to exclusively non-marine (beds KA 24) ostracod biofacies evidences a marine regressive event, presumably as response to the short-term sea-level fall event JBj3 (169.1 MA) of Haq (2017) [60], according to [21] through their sequence stratigraphic analysis of the Krachoua Formation. This emersion event of the Krachoua basin during the middle to late Bajocian time interval is supported by sedimentological features, notably, the increase in siliciclastic sediments toward the top of this series [21,24,26,27]. Similar contemporaneous palaeoenvironmental settings bearing marginal-marine to non-marine ostracods have been widely described from several localities, notably, France, Portugal, Spain, and England [1-18], as well as Tunisia and Morocco [19,20,61] of the northern and southern Tethyan margins, respectively.

\subsection{Biostratigraphy and Implication on Regional Stratigraphic Correlation}

Thus far, the ostracods of the Krachoua Formation have only been reported from the Tataouine area [19-21], southern Tunisia. This is the first detailed description of such ostracod fauna from the Medenine area, ca. $60 \mathrm{~km}$ more northward than this palaeogeographic domain, providing new insights on the lateral stratigraphic distribution of this fauna, their corresponding palaeoenvironmental settings, and a new tool for regional stratigraphic correlation of the Bajocian Krachoua series in southern Tunisia (Figure 6). Accordingly, the Kef El Anneba locality of the Medenine area represents the third section of the Bajocian Krachoua series bearing ostracods, within a north-south trend lateral correlation to their coeval fauna from the two previously studied sections of Kazzani [30] and Krachoua [19,20], both from the Tataouine area. The similarity mainly in the non-marine ostracod associations from these three sections allows us to detect and follow the spatio-temporal emersion phase within the Bajocian Krachoua basin in southern Tunisia as response to the sea level fall event JBj3 (169.1 MA) of Haq (2017) [60] (Figure 7), according to [21], and therefore provides 
new data for a reliable palaeogeographic scheme of this palaeogeographic domain during that time interval.

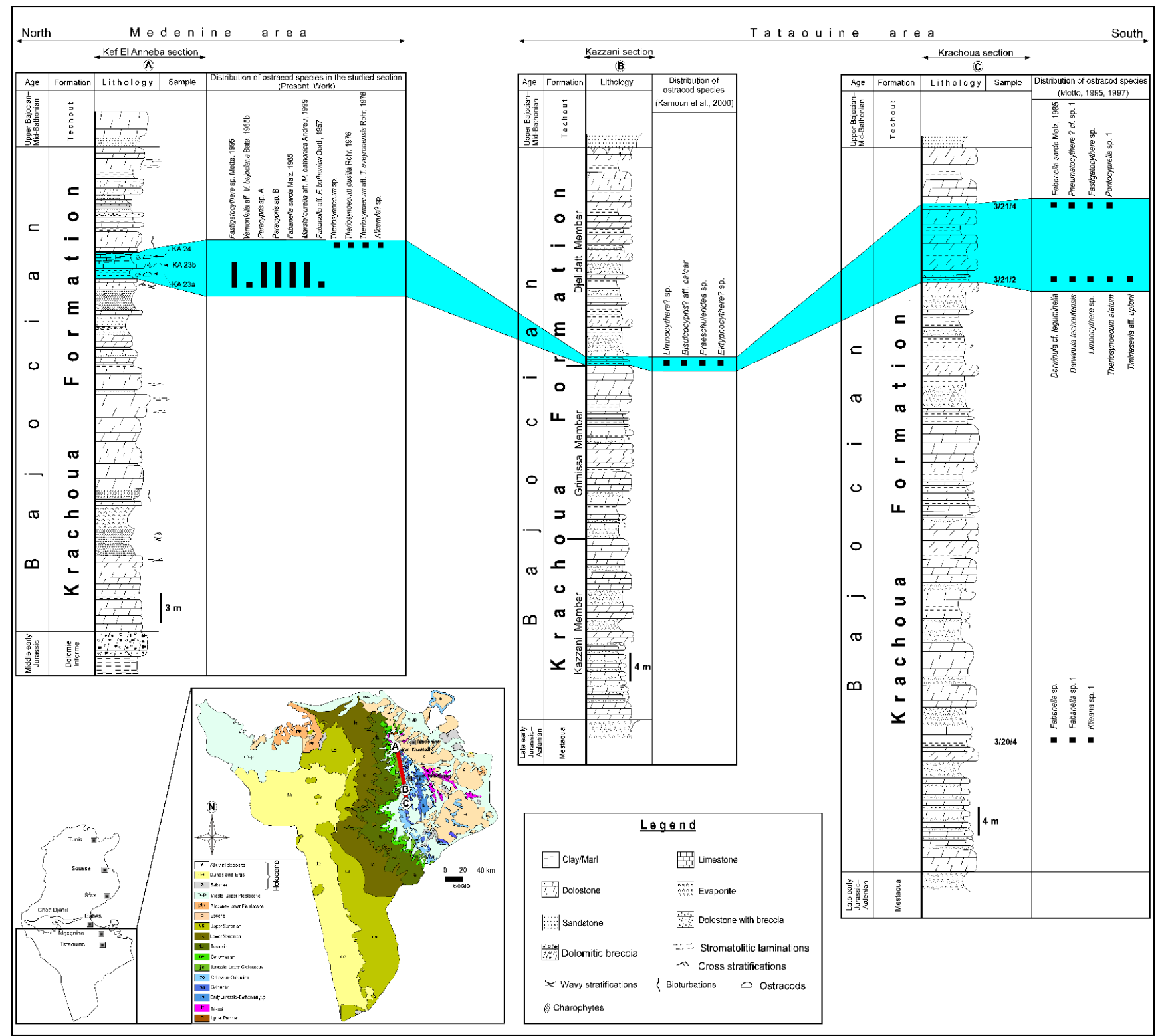

Figure 6. Regional stratigraphic correlation of the ostracod-bearing beds within the Krachoua Formation in the southern Tunisian palaeogeographic domain. 


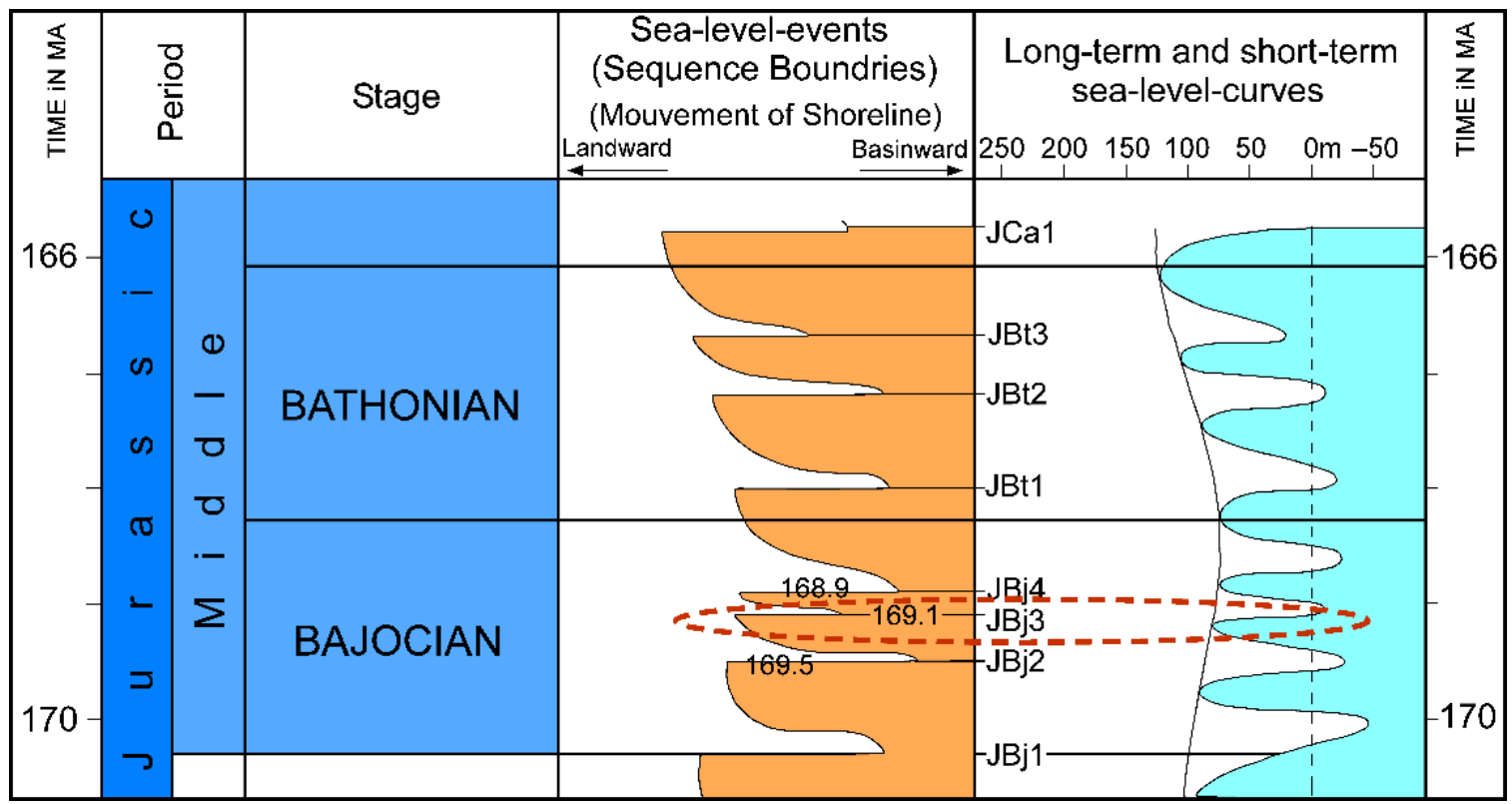

Figure 7. Chronostratigraphic calibration of the marginal-marine Bajocian event of southern Tunisia as response to the short-term sea-level fall event JBj3 (169.1 MA) of Haq (2017) [60].

\section{Conclusions}

Bajocian ostracod assemblages are herein described for first time from the Krachoua Formation, at the Kef El Anneba section of Medenine area, southern Tunisia. The ostracod association is composed of 11 brackish to freshwater species.

A combination of sedimentological and taphonomic data form the work of $[24,26,27]$ and palaeoecological analysis from the studied ostracod assemblages in the studied area give us new insights on the quasi-emersion of the Krachoua basin through the whole of the southern Tunisian domain, as response to the sea level fall event JBj3 (169.1 MA) of Haq (2017) [60], as previously suggested by [21].

The studied ostracod microfauna herein is yielded from a third, northernmost section in northern south Tunisia, providing us a potential tool for improving the stratigraphic accuracy of the Bajocian Krachoua Formation, as well as to establish its regional correlation in time and space and shedding new light on the palaeogeographic scheme of this domain during that time interval.

The recognized ostracod species from the studied series, notably, the non-marine ones, show affinities to those having been described from the Middle Jurassic of France [1,14] and England [4-7] and therefore support the hypothesis of the passive (by larger animals) long-distance dispersal of non-marine ostracods and charophytes and exchange between neighbouring islands from Laurasia and Gondwana. This has recently been demonstrated by [33] by means of a charophyte flora within the context of epicontinental conditions that prevailed worldwide during the Middle Jurassic [62]. Hence, our results give further arguments to support the hypothesis that Peri-Tethyan biogeography remained relatively uniform during the Middle Jurassic.

Author Contributions: Conceptualization, K.T. and Y.H.; Data curation, Y.H.; Formal analysis, L.T.; Funding acquisition, Y.H., F.E., A.S. and M.W.; Investigation, K.T., L.T., B.S., Y.H., A.H., F.E., A.S., M.F.Z. and M.W.; Methodology, K.T., L.T. and B.S.; Project administration, Y.H.; Supervision, F.K. and M.W.; Visualization, A.H.; Writing-original draft, K.T.; Writing-review \& editing, B.S., Y.H. and M.F.Z. All authors have read and agreed to the published version of the manuscript.

Funding: This study arose from the Tunisian research project of the ONM (Tunisian National Office of Mines, project "Cartographie Géologique et Stratigraphique des Formations Continentales de la Tunisie"). It is a contribution to UNESCO-IGCP 632 "Continental Crises of the Jurassic: Major 
Extinction Events and Environmental Changes within Lacustrine Ecosystems", subproject "Late Mesozoic lacustrine systems in Tunisia and their global correlation" (BS) and UNESCO IGCP Project 661 "The Critical Zone in Karst Systems", sub-project: 'Evolution of fossil blue hole limestones and the critical zone in a greenhouse world' (MW, KT), both within the scope of the Earth System Science (ESS) programme funded by the Austrian Academy of Sciences (ÖAW).

Institutional Review Board Statement: The study did not require ethical approval or involve humans.

Informed Consent Statement: The study did not involve humans.

Data Availability Statement: The study did not report any stored data.

Acknowledgments: Open Access Funding by the University of Vienna. The final version of this paper was emended by constructive remarks of three anonymous reviewers.

Conflicts of Interest: The authors declare no conflict of interest.

\section{References}

1. Andreu, B. Ostracodes du Bathonien Moyen et Supérieur des Grands-Causses, Sud de la France. Associations et Paléoenvironnements. Rev. Micropal. 1999, 42, 187-211. [CrossRef]

2. Azerêdo, A.C.; Cabral, M.C.; Ramalho, M.M.; Pereira, R. Overview of Microfossil Assemblages and Paleoecological Signatures in the Middle-Upper Jurassic Transitional Successions from the Lusitanian Basin, Portugal. Comm. Inst. Geol. Min. 2002, 89, 155-178.

3. Bate, R.H. Middle Jurassic Ostracoda from North Lincolnshire. Bull. Brit. Mus. Nat. Hist. Geol. 1963, 8, $173-219$.

4. $\quad$ Bate, R.H. Middle Jurassic Ostracoda from South Yorkshire. Bull. Brit. Mus. Nat. Hist. Geol. 1963, 9, 19-46.

5. Bate, R.H. Freshwater ostracods from the Bathonian of Oxfordshire. Palaeontology 1965, 8, 749-756.

6. Bate, R.H. Middle Jurassic Ostracoda from the Grey Limestone Series, Yorkshire. Bull. Brit. Mus. Nat. Hist. Geol. 1965, 11, 73-134.

7. Bate, R.H. The Bathonian Upper Estuarine Series of eastern England Part 1: Ostracoda. Bull. Brit. Mus. Nat. Hist. Geol. 1967, 14, 21-66.

8. Bate, R.H. Middle Jurassic (Aalenian-Bathonian). In Ostracods in British Stratigraphy; Whittaker, J.E., Hart, M.B., Eds.; Micropalaeontological Society, Special Publication, Geological Society: London, UK, 2009; pp. 100-223.

9. Colin, J.P. Les Ostracodes Limniques du Jurassique Européen. In Biostratigraphie du Jurassique Ouest-Européen et Méditerranéen; Cariou, P., Hantzpergue, P., Eds.; Bulletin du Centre de Recherches Elf Exploration Production: Boussens, France, 1997; Volume 17, pp. 273-279.

10. Oertli, H.J. Faunes d'Ostracodes du Mésozö̈que de France; Brill: Leiden, The Netherlands, 1963; p. 57.

11. Dépêche, F. Les Ostracodes d'une Plateforme Continentale au Jurassique, Recherches sur le Bathonien du Bassin Parisien; Unpublished, these d'état; Université. Pierre-et-Marie Curie: Paris, France, 1984; Volume 84, p. 419.

12. Dépêche, F. Lias superieur, Dogger, Malm. In Atlas des Ostracodes de France; Oertli, H.J., Ed.; Bulletin du Centre de Recherches Elf Exploration Production: Boussens, France, 1985; Volume 9, pp. 119-124.

13. Mojon, P.O. Les Formations Mésozoïques à Charophytes (Jurassique moyen-Crétacé inférieur) de la Marge Téthysienne NordOccidentale (Sud-Est de la France, Suisse Occidentale, Nord-Est de l'Espagne). Sédimentologie, Micropaléontologie, Biostratigraphie. Ph.D. Thesis, Université Joseph-Fourier-Grenoble I, Saint-Martin-d'Estréaux, France, 2001.

14. Oertli, H.J. Ostracodes Lacustres du Bathonian du Poitou (Bassin de Paris); Bernard, F., Bizon, J.J., Oertli, H.J., Eds.; Bulletin de la Société Géologique de France: Paris, France, 1957; Volume 6, pp. 753-770.

15. Rohr, W.M. Mitteljurassische Ostracoden aus den Grands Causses Süd-Frankreichs. Ph.D Thesis, Freie Universität, Berlin, Germany, 1976; p. 166

16. Sheppard, L.M. Middle Jurassic Ostracoda from Southern England and Northern France. Ph.D Thesis, University of London, London, UK, 1981.

17. Wakefield, M.I. Ostracoda and Palaeosalinity Fluctuations in the Middle Jurassic Lealt Shale Formation, Inner Hebrides, Scotland. Palaeontology 1995, 38, 583-617.

18. Wienholz, E. Neue Ostracoden aus dem Norddeutschen Callov. Freib. Forsch. Paläontologie 1967, $213,23-51$.

19. Mette, W. Ostracods from the Middle Jurassic of Southern Tunisia. Beringeria 1995, 16, 259-348.

20. Mette, W. Palaeoecology and Palaeobiogeography of the Middle Jurassic Ostracods of Southern Tunisia. Palaeogeog. Palaeoclimat. Palaeoecol. 1997, 131, 65-111. [CrossRef]

21. Kamoun, F.; Peybernès, B.; Montacer, M.; Ben Youssef, M. Sequence Stratigraphy, Micropalaeontology and Palaeogeography of the Jurassic Series of Southern Tunisia. In The Geology of Northwest Libya. Second Symposium on the Sedimentary Basins of Libya; Salem, M.J., Oun, K.K., Seddiq, H.M., Eds.; Earth Science Society of Libya (ESSL): Tripoli, Libya, 2000; pp. 79-98.

22. Busson, G. Le Mésozoïque Saharien. 1ère Partie: L'Extrême Sud Tunisien. Cent. Nat. Rech. Sci. Paris Géol. 1967, 8, 1-204.

23. Walley, C.D. Depositional History of Southern Tunisia and Northwestern Libya in Mid and Late Jurassic Time. Geol. Magaz. 1985, 212, 233-247. [CrossRef]

24. Kamoun, F. Le Jurassique du Sud Tunisien, Témoin de la Marge Africaine de la Téthys; Stratigraphie, Sédimentologie et Micropaléontologie. Ph.D. Thesis, Université de Toulouse, Toulouse, France, 1988; p. 330. 
25. Kamoun, F.; Ben Youssef, M.; Peybernès, B. Stratigraphie Séquentielle du Dogger et de la Base du Malm (Intervalle AalénienKimméridgien) de l'Extrême-Sud de la Tunisie. Com. Rend. Acad. Sci. Paris 1992, 315, 1373-1379.

26. Ben Ismail, M.H. Mixed Evaporitic Shallow Marine Carbonate and Siliciclastic Sedimentation of Jurassic Sequences in Southeast Tunisia. In Proceedings of the 8th IAS Regional Meeting of Sedimentology, Tunis, Tunisia, 1-3 April 1987; International Association of Sedimentologists: Algier, Algeria, 1987; pp. 80-82.

27. Ben Ismail, M.H.; M'Rabet, A. Evaporite, Carbonate, and Siliciclastic Transitions in the Jurassic Sequences of Southeastern Tunisia. Sed. Geol. 1990, 66, 65-82. [CrossRef]

28. Bouaziz, S. La Déformation Dans la Plate-Forme du Sud Tunisien (Dahar et Jeffara): Approche Multiscalaire et Pluridisciplinaire. Ph.D. Thesis, Université de Tunis, Tunis, Tunisia, 1986; p. 180.

29. Peybernès, B.; Alméras, Y.; Ben Youssef, M.; Kamoun, F.; Mello, J.; Rey, J.; Zargouni, F. Nouveaux Eléments de Datation Dans le Jurassique du Sud-Tunisien (Plate-Forme Saharienne). Comp. Rend. Acad. Sci. Paris 1985, 300, 113-119.

30. Ben Ismail, M.H.; Bouaziz, S.; Alméras, Y.; Clavel, B.; Donze, P.; Enay, R.; Ghanmi, M.; Tintant, H. Nouvelles donnée biostratigraphiques sur le Callovien et les faciès "purbecko-wealdiens" (Oxfordien à Vraconien) dans la region de Tataouine (Sud tunisien). Bull. Soc. Géolog. France 1989, 8, 353-360. [CrossRef]

31. Enay, R.; El Asmi, K.; Soussi, M.; Mangold, C.; Hantzpergue, P. Un Pachyerymnoceras Arabique Dans le Callovien Supérieur du Dahar (Sud Tunisien), Nouvel Elément de Datation du Membre Ghomrassène (Formation Tataouine); Corrélations Avec l'Arabie Saoudite et le Moyen-Orient. Comp. Rend. Geosci. 2002, 334, 1157-1167. [CrossRef]

32. Alméras, Y.; Enay, R.; Mangold, C.; Soussi, M.; El Asmi, K.; Hantzpergue, P. Observations à la Note: Mise en Évidence d'une Flore Oxfordienne Dans le Sud-Est de la Tunisie: Intérêts Stratigraphique et Paléoécologique par M. Ouaja. Geobios 2004, 37, 89-97, Erratum in Geobios 2005, 38, 691-695.

33. Tiss, L.; Trabelsi, K.; Kamoun, F.; Soussi, M.; Houla, Y.; Sames, B.; Martín-Closas, C. Middle Jurassic Charophytes from Southern Tunisia: Implications on Evolution and Paleobiogeography. Rev. Palaeob. Palynol. 2019, 263, 65-84. [CrossRef]

34. Nötzold, T. Die Präparation von Gyrogoniten und Kalkigen Charophyten-Oogonien aus Festen Kalksteinen. Monat. Deut. Akad. Wiss. Berl. 1965, 7, 216-221.

35. Trabelsi, K.; Touir, J.; Soulié-Märsche, I.; Martín-Closas, C.; Soussi, M.; Colin, J.P. Découverte des Charophytes de l'Albien Dans la Formation Kebar (Tunisie Centrale): Implications Paléoécologiques et Paléobiogéographiques. Ann. Paléontol. 2010, 96, 117-133. [CrossRef]

36. Trabelsi, K.; Sames, B.; Salmouna, A.; Piovesan, E.K.; Ben Rouina, S.; Houla, Y.; Touir, J.; Soussi, M. Ostracods from the Marginal Coastal Lower Cretaceous (Aptian) of the Central Tunisian Atlas (North Africa): Paleoenvironment, Biostratigraphy and Paleobiogeography. Rev. Micropaléontol. 2015, 58, 309-331. [CrossRef]

37. Trabelsi, K.; Soussi, M.; Touir, J.; Houla, Y.; Abbes, C.; Martín-Closas, C. Charophyte Biostratigraphy of the Non-Marine Lower Cretaceous in the Central Tunisian Atlas (North Africa): Palaeobiogeographic Implications. Cret. Res. 2016, 67, 66-83. [CrossRef]

38. Trabelsi, K.; Sames, B.; Nasri, A.; Piovesan, E.K.; Ferhi, F.; Skanji, A.; Houla, Y.; Soussi, M.; Wagreich, M. Ostracods as Proxies for Marginal Marine to Non-Marine Intervals in the Mid-Cretaceous Carbonate Platform of the Central Tunisian Atlas (North Africa): Response to Major Short-Term Sea-Level Falls. Cret. Res. 2021, 117, 104581. [CrossRef]

39. Martin, J.W.; Davis, G.E. An Updated Classification of the Recent Crustacea. Nat. Hist. Mus. Los Angel. Cty. Sci. Ser. 2001, 39, $1-124$.

40. Meisch, C.; Smith, R.J.; Martens, K. A Subjective Global Checklist of the Extant Non-Marine Ostracoda (Crustacea). Eur. J. Taxon. 2019, 492, 1-135. [CrossRef]

41. Horne, D.J. Ostracod Biostratigraphy and Palaeoecology of the Purbeck Limestone Group in Southern England. Spec. Pap. Palaeontol. 2002, 68, 1-18.

42. Soulimane, C.; Reolid, M.; Marok, A. Ostracod Assemblages from the Uppermost Pliensbachian and Lower Toarcian of the Traras Mountains (Tlemcen Domain, North Algeria). Arab. J. Geosci. 2017, 10, 1-24. [CrossRef]

43. Malz, H.; Hofmann, K.; Radke, G.; Cherchi, A. Biostratigraphy of the Middle Jurassic of NW Sardinia by Means of Ostracods. Senckenb. Leth. 1985, 66, 299-345.

44. Dépêche, F. Etude Micropaleontologique du Bathonien des Causses du Quercy (Region de Cajaro). Rev. Micropaleontol. 1968, 11, 210-216.

45. Sames, B. Early Cretaceous Theriosynoecum Branson 1936 in North America and Europe. Micropaleontology 2011, 57, $291-344$.

46. Sames, B. Glossary of Morphologic Terms of Late Mesozoic Non-Marine Ostracoda, Relevant to Theriosynoecum Branson 1936 and Cypridea Bosquet 1852. Micropaleontology 2011, 57, 433-454.

47. Sames, B. Combined References for Taxonomic Studies in Early Cretaceous Non-Marine Ostracoda of North America. Micropaleontology 2011, 57, 455-465.

48. Martens, K.; Rossetti, G.; Horne, D.J. How Ancient Are Ancient Asexuals? Proc. R. Soc. Lond. Biol. Sci. 2003, 270, 723-729. [CrossRef]

49. Fürsich, F.T.; Freytag, S.; Röhl, J.; Schmid, A. Palaeoecology of Benthic Associations in Salinity-Controlled Marginal Marine Environments: Examples from the Lower Bathonian (Jurassic) of the Causses (Southern France). Palaeogeogr. Palaeoclim. Palaeoecol. 1995, 113, 135-172. [CrossRef]

50. Neale, J.W. Ostracods and Palaeosalinity Reconstruction. In Ostracoda in the Earth Sciences; Dedeckker, P., Colin, J.P., Peypouquet, J.P., Eds.; Elsevier: Amsterdam, The Netherlands, 1988; pp. 125-155. 
51. Colin, J.P.; Dépêche, F. Faunes d'Ostracodes Lacustres des Bassins Intracratoniques d'âge Albo-Aptien en Afrique de l'Ouest (Cameroun, Tchad) et au Brésil: Considérations d'Ordre Paléoécologique et Paléobiogéographique. Afri. Geosci. Rev. 1997, 4, 431-450.

52. Nye, E.; Feist-Burkhardt, S.; Horne, D.J.; Ross, A.J.; Whittaker, J.E. The Palaeoenvironment Associated with a Partial Iguanodon Skeleton from the Upper Weald Clay (Barremian, Early Cretaceous) at Smokejacks Brickworks (Ockley, Surrey, UK), Based on Palynomorphs and Ostracods. Cret. Res. 2008, 29, 417-444. [CrossRef]

53. Ayress, M.A.; Whatley, R.C. Early Cretaceous non-Marine Ostracoda from the North Falkland Basin, South Atlantic. Palaeontology 2014, 57, 1143-1175. [CrossRef]

54. Oertli, H.J. The Aspect of Ostracods Fauna: A possible new tool in petroleum sedimentology. In Paléoécologie des Ostracodes; Oertli, H.J., Ed.; Bulletin du Centre de Recherches: Paris, France, 1971; pp. 137-151.

55. Weiß, M. Stratigraphie und Mikrofauna im Kimmeridge SE-Niedersachsens unter Besonderer Berücksichtigung der Ostracoden. Ph.D. Thesis, Technische Universität Clausthal, Clausthal-Zellerfeld, Germany, 1995. Volume 48. pp. 1-274.

56. Boomer, I.; Horne, D.J.; Slipper, I.J. The Use of Ostracods in Palaeoenvironmental Studies, or What Can You Do with an Ostracod Shell. In Bridging the Gap-Trends in the Ostracode Biological and Geological Sciences; Park, L.E., Smith, A.J., Eds.; The Paleontological Society Papers: Cambridge, UK, 2003; Volume 9, pp. 153-179.

57. Whatley, R.C. The application of Ostracoda to paleoenvironmental analysis. In Applications of Ostracoda, Proceedings of the Eighth International Symposium on Ostracoda, Houston, TX, USA, 26-29 July; Department of Geosciences, University of Houston: Houston, TX, USA, 1983; pp. 51-77.

58. Browers, E.M. Sediment transport detected from the analysis of ostracod population structure: An example from the Alaskan continental shelf. In Ostracoda in Earth Sciences; Dedeckker, P., Colin, J.P., Peypouquet, J.P., Eds.; Elsevier: Amsterdam, The Netherlands, 1988; pp. 231-244.

59. Crasquin-Soleau, S.; Vaslet, D.; Le Nindre, Y.M. Ostracods as Markers of the Permian/Triassic boundary in the Khuff Formation of Saudi Arabia. Palaeontoloy 2005, 48, 853-868. [CrossRef]

60. Haq, B.U. Jurassic Sea-Level Variations: A Reappraisal. GSA Today 2017, 28, 4-10. [CrossRef]

61. Mojon, P.O.; Haddoumi, H.; Charriére, A. Nouvelles Données sur les Charophytes et Ostracodes du Jurassique Moyen-Supérieur-Crétacé Inférieur de l'Atlas Marocain; Carnets De Géologie/Notebooks on Geology: Brest, France, 2009; pp. 1-39.

62. Dercourt, J.; Fourcade, E.; Cecca, F.; Azéma, J.; Enay, R.; Bassoullet, J.P.; Cottereau, N. Palaeoenvironment of the Jurassic System in the Western and Central Tethys (Toarcian, Callovian, Kimmeridgian, Tithonian): An Overview. Geobios 1994, 17, 625-644. [CrossRef] 